\title{
Influence of single nucleotide polymorphisms of vitamin D receptor-gene on the level of osteoassociated hormones linkage with postmenopausal osteoporosis
}

\author{
D.S. Ziablitsev, O.S. Larin
}

Ukrainian Science-Practical Centre of Endocrine Surgery, Transplantation of Endocrine Organs and Tissues Ministry of Healthcare of Ukraine, Kyiv; e-mail: denis898@ukr.net; zsv@endosurg.com.ua

\begin{abstract}
The levels of osteoassociated hormones, macroelements, interleukines, cyclic nucleotides and activity of alkaline phosphatase were being detected in the blood plasma of 74 postmenopausal women with and without osteoporosis $(O P)$. Bone mineral density (BMD) and the metacarpal index were being assessed according to the results of densitometry. The allele polymorphisms vitamin D receptor gene (VDR) Cdx2 (rs11568820) and TaqI (rs731236) were being identified with the help of the polymerase chain reaction. The major genotype CC TaqI was found in the group without OP 3.4 times more often than with OP, while the minor genotype TT was found 3.4 times more often with the presence of OP. The presence of the genotype $C C$ TaqI decreased the risk of OP progress by 5.5 times, and the genotype TT TaqI increased by 5.4 times. The presence of the minor allele T was associated with the higher levels of interleukin $1 \beta, B M D$ and lower testosterone blood level. The major homozygote AA Cdx2 was found in women without OP 2.9 times more often, while the minor genotype GG-5.4 times more often with the presence of OP. The presence of the major homozygote decreased the risk of OP progress by more than 5.3 times, while the minor homozygote increased the risk by 8 times. The presence of the minor allele $G$ in the genotype was associated with the increase of parathyroid hormone, phosphorus, magnesium, alkaline phosphatase activity in blood, BMD and with the decrease of testosterone, progesterone and calcium blood levels.

Key words: postmenopausal osteoporosis: hormones: VDR: polymorphism Cdx2 (rs11568820): polymorphism TaqI (rs731236).
\end{abstract}

\section{INTRODUCTION}

Postmenopausal osteoporosis (OP) - is a systemic disease with a multi-factor character, that appears in postmenopausal women as a result of the deficit of sex hormones and first of all the estrogen [1]. The disease is characterized by reduction in bone mass and microarchitectonic deterioration of bone tissue, which leads to the increase in the risk of bone fractures [2]. The regulation of the bone tissue's remodelling implements at the local level (cytokines and growth factors) and the system level (hormones) $[3,4]$. Parathyroid hormone (PTH) and calcitonin (CT) are the main regulatory hormones of the calcium-phosphoric metabolism. The specific protein of bone matrix - osteocalcin (OC) is the marker of the remodelling. The level of calcium $(\mathrm{Ca})$ in the blood stream depends on the process of its absorption in the small intestine, which, in turn, is regulated by the metabolites of vitamin D with a hormonal activity - calcitriol, which activates nuclear receptor to vitamin D (VDR), that increases the expression of gene in more than 30 target organs [5-7]. It is the physiological transcription of VDR that realizes in full effects of vitamin's D metabolites on bone's tissue, which is characteristic for typical genetically-determined processes [6, 8]. The initiation of transcription is carried out by two codons in the DNA sequence of VDR. TaqI-polymorphism in the second gene's exon of VDR emerges as a result of the substitution of thymine for cytosine in the first of two sites.

(C) D.S. Ziablitsev, O.S. Larin 
Consequently, protein, shorter by three amino acids, is synthesized (the transcription begins with the second site of initiation, which is localized for three codons further) $[8,9]$. It leads to disturbance of $\mathrm{Ca}$ absorption in the small intestine and to hypocalcemia. Polymorphism in the site restriction Cdx2 of VDR gene leads to reduction of bone mass density (BMD) and increases the risk of bone fracture $[10,11]$, also it has influence on variations of BMD [12]. The absence of Cdx2-polymorphism of VDR gene has a protective role in the progress of osteoporosis [11-13].

Therefore, the aim of these work is to define the connection between single nucleotide polymorphism of VDR gene (TaqI (T61968C; rs731236) and $\mathrm{Cdx} 2$ (G3731A; rs11568820) and the risk of the development of the OP, the level of osteoassociation hormones and the biologically active substances in postmenopausal women.

\section{MATERIAL AND METHODS}

74 women in postmenopause were examined. Among them 30 patients $(40,5 \%)$ without OP formed the control group of genetic research (control). 44 women with the manifestation of OP $(59,5 \%)$ formed the group of study (cases). Bone mineral density (BMD) and the metacarpal index (MCI) were being assessed according to the results of densitometry ("QDR-4500-Delphi-Hologic", USA). Using the biochemical analyzer "BS-200" (China) the activity of ALP, $\mathrm{Ca}$, phosphorus $(\mathrm{P})$ and magnesium $(\mathrm{Mg})$ was examined in the blood serum ("La Chema", Czech Republic). The content of PTH, CT, OC and also estradiol (E2), progesterone (PG), testosterone (TS), cortisol (CS), insulin (IN), triiodthyronine (T3), thyroxine (T4), cyclic adenosine monophosphate (cAMP), interlikine (IL) $1 \beta$ and tumor necrosis factor alpha (TNF $\alpha$ ) (sets "VectorBest", Russia; "Amercham pharmacia biotech", Great Britain; "DRG”, USA) was studied using the immunoassay method. Single nucleotide polymorphisms (SNP) were detected by the polymerase chain reaction ("OsteoGen-
M", Russia) by the standard method: the isolation of DNA, the conduction of amplification reaction with specific primers, enzymatic hydrolysis of amplification products, electrophoretic separation with a subsequent registration of the obtained DNA fragments transient UV-light. After electrophoresing of fission products their enzymatic hydrolysis was carried out. Positive control was noted when there appeared bends of proper sizes fitting the sizes of the amplicon's fragment. Statistical calculation was made with the help of the «STATISTIKA 7.0» (StatSoft, Inc.) program. The statistical significance of the distinction in frequency distribution of the genotypes occurrence between the groups was defined by F-test. Reliability in distinction of genotypes and alleles distribution between the groups, as well as complience of the distribution according to the Hardy-Weinberg equilibrium (HWE) were estimated by analysing of linkage tables by $\chi^{2}$ criterion. Distribution of the genotypes in the groups with and without OP was considered reliable providing an accordance to HWE for the groups of control and cases.

The level of genotype association with OP was determined according to the odds ratios (OR), that characterizing the relative risk (chances) for a disease development in the given case depending on the allelic polymorphism of the tested gene. The level of OR higher than 1 tells for the trustworthy increase in risk, provided that it is in the confidence interval $(\mathrm{CI}=95 \%)$. The level of OR lower than 1 tells for the trustworthy decrease in risk the credibility of the allelic genes variants influence on the clinical-laboratory rates was estimated by using ANOVA/MANOVA for the F-test. The credibility of the distinction between the averages was estimated by the Student t-test.

\section{RESULTS AND THEIR DISCUSSION}

The results of the study (Fig. 1) have indicated that frequencies of VDR genotypes TaqI distribution represented a significant difference between the groups of patients in case of the 


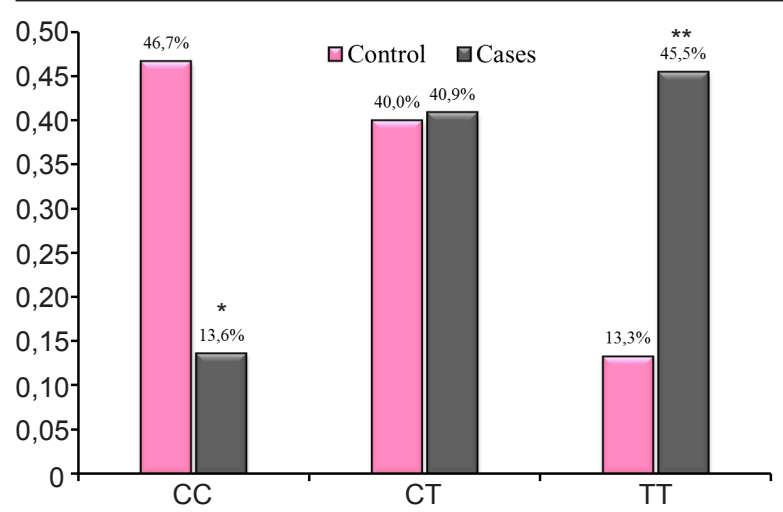

Fig.1. Frequencies (\%) distribution of the genotype polymorphisms TaqI VDR gene. * the significance of the frequencies distinction between the groups based on the F-test $\left(\mathrm{p}_{(\mathrm{F})}=0,03\right)$; ** the significance of the frequencies distinction between the groups based on the F-test $\left(\mathrm{p}_{(\mathrm{F})}=0,04\right)$

homozygous genotypes occurrence. Thus major homozygous genotype (CC) occurred in the group without OP in 46,7\% cases, and with OP - in 13,6\% (3.4 times more often, which was significant according to the F-test). The minor homozygous genotype, on the contrary, was found more often involving presence of OP $45,5 \%$, vs $13,3 \%$ in the group without OP (3.4 times more often, which was also significant according to the F-test). Frequencies distribution of the heterozygous genotypes did not differ one from another.

As it can be seen from the table 1, the dependence of the VDR genotypes distribution on the presence or absence of OP respectively was detected $\left(p\left(\chi^{2}\right)=0,04\right)$. HWE for the group without OP and with it for polymorphic variant of VDR gene agreed, since, respectively: $\chi^{2}=0,15 ; p=0,97$ and $\chi^{2}=0,18 ; p=0,96$.

The presence of major homozygote (CC) decreased the risk of OP development by 5.6 times $(\mathrm{OR}=0,18 ; \mathrm{CI}=0,04-0,88)$, while the homozygous state of the minor genotype (TT) increased the risk by 5.4 times $(\mathrm{OR}=5,42 ; \mathrm{CI}=0,98-29,92)$.

Therefore, it can be affirmed that the presence of the major homozygote CC TaqI had a protective role to the OP development, whereas the presence of the minor homozygote TT, on the contrary, was conducive to the OP development. The risk of the OP development was decreased by 5.5 times in the first case, and in the second case it was increased by 5.4 times.

The obtained conclusions agreed with the data displayed in the table 1 . The minor allele (T) presence in genotype increased the risk of OP development nearly by 4 times $(\mathrm{OR}=3,87$; $\mathrm{CI}=1,45-10,33)$.

The VDR gene polymorphism TaqI reliably influenced the level of TS, IL1 $\beta$ in the blood and also the BMD (table 3 ).

Herewith the presence of the minor genotype TT was associated with the higher levels of IL1 $\beta$ and BMD. At the same time, the presence of the minor genotype TT favoured the lower TS blood level. It represented the biological role of these regulatory factors in the bone tissue mineralization process and agreed with the previously

Table 1. The significance of the genotype polymorphisms TaqI VDR gene distribution between the groups of women with and without $\mathrm{OP}$ and odds ratio in association with their genotypes

\begin{tabular}{c|ccc|c|c|c|}
\hline Genotypes & Control & Cases & $\chi^{2}$ & $\mathrm{p}\left(\chi^{2}\right)$ & OR & 95\% confidence interval \\
\hline CC & 14 & 6 & & 0,18 & $0,04-0,88$ \\
CT & 12 & 18 & 6,44 & 0,04 & 1,04 & $0,27-3,96$ \\
TT & 4 & 20 & & & 5,42 & $0,98-29,92$ \\
\hline
\end{tabular}

Table 2. The significance of the allele polymorphisms TaqI VDR gene distribution between the groups $(p(\chi 2))$ and odds ratio (OR)

\begin{tabular}{cccccccc|c|}
\hline Allele & Control & Cases & $\chi^{2}$ & $\mathrm{p}\left(\chi^{2}\right)$ & OR & $95 \%$ confidence interval \\
\hline $\mathrm{C}$ & 20 & 15 & 7,59 & 0,006 & 0,26 & $0,10-0,69$ \\
$\mathrm{~T}$ & 10 & 29 & & & 3,87 & $1,45-10,33$ \\
\hline
\end{tabular}


Table 3. The influence of the genotype polymorphisms TaqI VDR gene on clinical-laboratory $\operatorname{rates}(\mathrm{M} \pm \mathrm{m})$ in women with $\mathrm{OP}$

\begin{tabular}{|c|c|c|c|c|c|}
\hline \multirow{2}{*}{ Rates } & \multicolumn{3}{|c|}{ Genotypes } & \multirow{2}{*}{$\mathrm{F}$} & \multirow{2}{*}{$\mathrm{P}$} \\
\hline & $\mathrm{CC}(\mathrm{n}=20)$ & $\mathrm{CT}(\mathrm{n}=30)$ & TT $(n=24)$ & & \\
\hline PTH; pg/ml & $27,67 \pm 3,56$ & $38,89 \pm 7,48$ & $55,40 \pm 6,27$ & 3,23 & 0,06 \\
\hline $\mathrm{CT} ; \mathrm{pg} / \mathrm{ml}$ & $8,67 \pm 1,08$ & $8,78 \pm 1,16$ & $8,00 \pm 0,87$ & 0,19 & 0,82 \\
\hline $\mathrm{OC} ; \mathrm{ng} / \mathrm{ml}$ & $13,00 \pm 1,02$ & $15,89 \pm 3,94$ & $17,40 \pm 0,57$ & 2,81 & 0,085 \\
\hline $\mathrm{E} 2 ; \mathrm{pmol} / 1$ & $43,33 \pm 32,54$ & $32,89 \pm 12,68$ & $11,90 \pm 1,75$ & 2,10 & 0,15 \\
\hline PG; nmol/1 & $25,67 \pm 10,35$ & $26,56 \pm 3,96$ & $22,20 \pm 3,63$ & 0,36 & 0,70 \\
\hline $\mathrm{TS} ; \mathrm{nmol} / 1$ & $6,50 \pm 0,34$ & $5,03 \pm 0,90$ & $3,15 \pm 0,87$ & 3,54 & 0,48 \\
\hline $\mathrm{CS} ; \mathrm{nmol} / \mathrm{l}$ & $453,00 \pm 52,94$ & $533,00 \pm 82,67$ & $495,00 \pm 21,88$ & 0,62 & 0,54 \\
\hline $\mathrm{IN} ; \mathrm{mcMhO} / \mathrm{ml}$ & $12,67 \pm 1,78$ & $11,33 \pm 0,90$ & $12,20 \pm 1,29$ & 0,26 & 0,77 \\
\hline $\mathrm{T} 4 ; \mathrm{nmol} / 1$ & $122,33 \pm 5,40$ & $109,22 \pm 5,21$ & $111,60 \pm 6,51$ & 0,70 & 0,51 \\
\hline $\mathrm{T} 3 ; \mathrm{nmol} / 1$ & $1,67 \pm 0,11$ & $2,01 \pm 0,16$ & $2,17 \pm 0,13$ & 2,27 & 0,13 \\
\hline cAMP; ng/ml & $4,67 \pm 0,41$ & $4,89 \pm 0,41$ & $4,70 \pm 0,50$ & 0,06 & 0,94 \\
\hline IL $1 \beta ; \mathrm{pg} / \mathrm{ml}$ & $10,34 \pm 2,68$ & $11,44 \pm 1,78$ & $15,60 \pm 1,10$ & 3,64 & 0,04 \\
\hline $\mathrm{TNF} 1 \alpha ; \mathrm{pg} / \mathrm{ml}$ & $54,33 \pm 3,51$ & $57,27 \pm 0,18$ & $54,35 \pm 1,32$ & 2,22 & 0,14 \\
\hline ALP; U/1 & $139,34 \pm 15,00$ & $146,67 \pm 6,26$ & $123,70 \pm 9,53$ & 0,82 & 0,82 \\
\hline $\mathrm{Ca} ; \mathrm{mg} / \mathrm{l}$ & $60,33 \pm 0,82$ & $59,47 \pm 0,79$ & $57,62 \pm 0,80$ & 2,48 & 0,11 \\
\hline $\mathrm{P} ; \mathrm{mg} / \mathrm{l}$ & $382,87 \pm 9,71$ & $406,79 \pm 9,20$ & $419,20 \pm 8,15$ & 2,66 & 0,09 \\
\hline $\mathrm{Mg} ; \mathrm{mg} / \mathrm{l}$ & $32,63 \pm 3,16$ & $34,07 \pm 1,09$ & $34,67 \pm 1,22$ & 0,39 & 0,60 \\
\hline BMD; SD & $1,39 \pm 0,18$ & $1,57 \pm 0,01$ & $2,16 \pm 0,09$ & 7,20 & 0,0047 \\
\hline MCI; s.u. & $0,41 \pm 0,02$ & $0,41 \pm 0,01$ & $2,16 \pm 0,09$ & 1,00 & 0,38 \\
\hline
\end{tabular}

obtained results $[9,13]$. The highest value of the F-test $(F=7,2 ; p=0,0047)$ was noted for BMD.

Polymorphism in the site of connection with the transcription factor $\mathrm{Cdx} 2$ in the promoter region of VDR gene is associated with the level of $\mathrm{Ca}$ absorption in an intestine and with the receptor's activation to vitamin D [11]. It is shown in our study (Fig.2), that the major homozygote (AA) was found in women without OP in 53,3\% cases, and with OP approximately three times less (in 18,2\% cases). In other words, genotype (AA) in the group without OP symptoms was found 2,9 times more often, which is statistically significant according to F-test. The minor homozygous genotype (GG), on the contrary, was found 5.4 times more often: with OP - in 36,4\% cases vs $6,7 \%$ in the group without OP, that is also statistically significant according to F-test. Frequencies of the distribution of heterozygous genotypes did not differ one from another.

As in the preceding case (tabl. 1), the dependence of genotype polymorphisms $\mathrm{Cdx} 2$

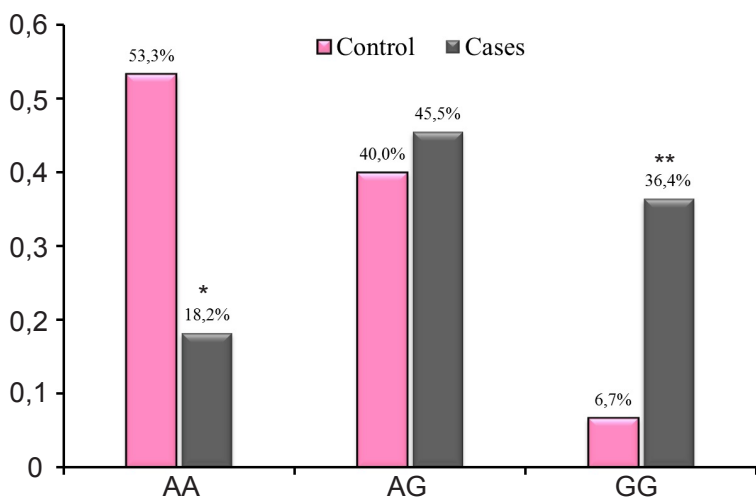

Fig. 2 Frequencies (\%) of the genotype polymorphisms Cdx2 VDR gene distribution. * the statistical significance of the frequencies distinction between the groups basing on F-test $(\mathrm{p}(\mathrm{F})=0,02) ; * *$ the statistical significance of the frequencies distinction between the groups basing on F-test $(p(F)=0,04)$ 
VDR gene on the presence or absence of OP $\left(\mathrm{p}\left(\chi^{2}\right)=0,04\right)$ was revealed (table 4$)$. HWE for the groups with and without OP for the polymorphic variant of Cdx2 polymorphism (G3731A)

Table 4. The significance of the allele polymorphisms Cdx2 VDR gene distribution between the groups (p( $\chi 2))$ and odds ratio (OR)

\begin{tabular}{c|c|c|c|c|c|c|}
\hline Genotype & Control & Cases & $\chi^{2}$ & $\mathrm{p}\left(\chi^{2}\right)$ & OR & $95 \%$ confident interval \\
\hline AA & 16 & 8 & & 0,19 & $0,04-0,86$ \\
AG & 12 & 20 & 6,49 & 0,04 & 1,25 & $0,33-4,73$ \\
GG & 2 & 16 & & & 8,00 & $0,88-72,70$ \\
\hline
\end{tabular}

was respectively (according $\chi^{2}=0,01 ; p=1,04$ and $\left.\chi^{2}=0,08 ; p=1,00\right)$. The presence of the major homozygote (AA) decreased the risk of OP progress by 5.3 times $(\mathrm{OR}=0,19 ; \mathrm{CI}=0,04$ $0,86)$, while the homozygosis state of the minor genotype (GG) increased the risk by more than 8 times $(\mathrm{OR}=8,00 ; \mathrm{CI}=0,88-72,70)$.

Accordingly, the presence the major homozygote genotype of the Cdx2 VDR gene (AA) had a protective role to the OP development, whereas the presence of the minor homozygote (GG), on the contrary, was conducive to the OP development. The risk of the OP development decreased by 5.3 times in the first case, and in the second case it increased by 8.0 times. It corresponded to the obtained data on the VDR gene polymorphism (T61968C) [2].

The data, displayed in the table 5 confirmed the identified patterns. The presence of the minor allele $(\mathrm{G})$ in the genotype increased the risk of OP development almost by 4 times $(\mathrm{OR}=3,97$; $\mathrm{CI}=1,45-10,88)$.

The polymorphism Cdx2 of the VDR gene reliably influenced the levels of $\mathrm{PTH}, \mathrm{PG}, \mathrm{TS}$, $\mathrm{Ca}, \mathrm{P}, \mathrm{Mg}, \mathrm{ALP}$ activity in blood and BMD (table 6).

According to the data of the conducted ANOVA/MANOVA, the presence of the minor genotype GG was associated with the increase of PTH, P, Mg, ALP-activity in the blood and BMD.
Herewith the presence of genotype GG led to the decrease of PG, TS and Ca blood levels. The greatest rate for the $\mathrm{F}$-test $(\mathrm{F}=13,85 ; \mathrm{p}=0,00014)$ was noted for the ALP-activity, which also confirmed the potential impact of the minor allele (G) on the process of the OP development.

\section{CONCLUSIONS}

The major genotype CC TaqI of the VDR gene was found in the group without OP 3.4 times more often than with OP, while the minor genotype TT was found 3.4 times more often with the presence of OP. The presence of the genotype CC TaqI decreased the risk of OP progress by 5.5 times, and the genotype TT TaqI - increased by 5.4 times. The presence of the minor allele $\mathrm{T}$ was associated with the higher levels of IL1 $\beta$, BMD and lower TS blood level.

The major homozygote AA Cdx2 of the VDR gene was found in women without OP 2.9 times more often, while the minor genotype GG -5.4 times more often with the presence of OP. The presence of the major homozygote decreased the risk of OP development by more than 5.3 times, while the minor homozygote increased the risk by 8 times. The presence of the minor allele $\mathrm{G}$ in the genotype was associated with the increase of PTH, P, Mg, ALP-activity in blood, BMD and with the decrease of PG, TS and Ca blood levels.

Table 5 The significance of distinction the VDR gene allele distribution between the groups and the odds ratio (OR)

\begin{tabular}{c|c|c|c|c|c|c|}
\hline Alleles & Control & Cases & $\chi^{2}$ & $\mathrm{p}\left(\chi^{2}\right)$ & OR & $95 \%$ confidence interval \\
\hline A & 22 & 18 & 7,55 & 0,006 & 0,25 & $0,09-0,69$ \\
G & 8 & 26 & & & 3,97 & $1,45-10,88$ \\
\hline
\end{tabular}


Influence of single nucleotide polymorphisms of vitamin D receptor-gene

Table 6. The influence of the genotype polymorphisms Cdx2 VDR gene on clinical-laboratory $\operatorname{rates}(\mathrm{M} \pm \mathrm{m})$ in women with $\mathrm{OP}$

\begin{tabular}{|l|c|c|c|c|c|}
\hline \multirow{2}{*}{ Rates } & \multicolumn{3}{|c|}{ Genotypes VDR $(-3731 \mathrm{~A} / \mathrm{G})$} & \multirow{2}{*}{$\mathrm{F}$} & \multirow{2}{*}{$\mathrm{P}$} \\
\cline { 2 - 4 } PTH; pg/ml & $\mathrm{AA}(\mathrm{n}=24)$ & $\mathrm{AG}(\mathrm{n}=32)$ & $\mathrm{GG}(\mathrm{n}=18)$ & & \\
CT; pg/ml & $50,00 \pm 11,22$ & $31,30 \pm 6,97$ & $59,25 \pm 4,08$ & 6,18 & 0,0095 \\
OC; ng/ml & $9,50 \pm 1,20$ & $8,30 \pm 0,89$ & $8,00 \pm 1,61$ & 0,39 & 0,68 \\
E2; pmol/1 & $14,75 \pm 1,44$ & $15,20 \pm 1,24$ & $18,13 \pm 0,62$ & 2,97 & 0,07 \\
PG; nmol/1 & $35,50 \pm 26,49$ & $31,10 \pm 10,71$ & $11,50 \pm 2,84$ & 1,36 & 0,28 \\
TS; nmol/1 & $36,75 \pm 3,42$ & $27,10 \pm 3,38$ & $15,00 \pm 2,31$ & 10,99 & 0,0006 \\
CS; nmol/1 & $6,67 \pm 0,51$ & $4,75 \pm 0,81$ & $2,76 \pm 0,90$ & 5,27 & 0,015 \\
IN; mcMhO/ml & $425,75 \pm 76,69$ & $542,00 \pm 40,96$ & $497,88 \pm 36,63$ & 1,67 & 0,22 \\
T4; nmol/1 & $12,25 \pm 0,78$ & $10,80 \pm 1,44$ & $13,13 \pm 2,01$ & 1,29 & 0,29 \\
T3; nmol/1 & $117,00 \pm 7,45$ & $112,30 \pm 7,08$ & $109,38 \pm 10,62$ & 0,27 & 0,77 \\
cAMP; ng/ml & $1,72 \pm 0,13$ & $2,04 \pm 0,13$ & $2,19 \pm 0,17$ & 2,17 & 0,14 \\
IL1 $\beta ; \mathrm{pg} / \mathrm{ml}$ & $4,00 \pm 0,47$ & $5,00 \pm 0,44$ & $4,88 \pm 0,62$ & 0,98 & 0,39 \\
TNF1 $\alpha ; \mathrm{pg} / \mathrm{ml}$ & $15,25 \pm 2,51$ & $11,00 \pm 1,71$ & $14,87 \pm 1,45$ & 2,37 & 0,12 \\
ALP; U/1 & $55,10 \pm 2,34$ & $56,49 \pm 0,94$ & $54,57 \pm 1,89$ & 0,74 & 0,50 \\
Ca; mg/l & $102,50 \pm 9,89$ & $143,80 \pm 6,39$ & $152,13 \pm 4,48$ & 13,85 & 0,00014 \\
P; mg/l & $60,90 \pm 0,12$ & $59,50 \pm 0,70$ & $56,73 \pm 0,91$ & 8,55 & 0,0022 \\
Mg; mg/l & $382,13 \pm 8,27$ & $405,06 \pm 10,17$ & $427,83 \pm 8,38$ & 6,62 & 0,0065 \\
BMD; SD & $30,75 \pm 2,21$ & $33,68 \pm 0,85$ & $36,42 \pm 1,38$ & 5,44 & 0,013 \\
MCI; s.u. & $1,83 \pm 0,18$ & $1,51 \pm 0,17$ & $2,20 \pm 0,14$ & 6,65 & 0,0064 \\
& $0,39 \pm 0,01$ & $0,41 \pm 0,01$ & $0,39 \pm 0,02$ & 2,51 & 0,107 \\
\hline
\end{tabular}

Д. С. Зябліцев, О. С. Ларін

\section{ВПЛИВ ОДНОНУКЛЕОТИДНИХ ПОЛІМОР- ФIЗМIВ ГЕНA VDR HA РIBEHЬ ОСТЕОАC- СОЦІЙОВАННИХ ГОРМОНІВ ПРИ ПОСТ- МЕНОПАУЗНОМУ ОСТЕОПОРОЗІ}

У плазмі крові 74 жінок у постменопаузному періоді 3 та без остеопорозу визначали вміст остеоасоційованих гормонів, макроелементів, інтерлейкінів, циклічних нуклеотидів та активність лужної фосфатази. Мінеральну щільність кістки (МЩК) і метакарпальний індекс оцінювали згідно з результатами денситометрії. За допомогою полімеразної ланцюгової реакції виявляли алельні поліморфізми гена рецептора вітаміну D (VDR) Cdx2 (rs11568820) та TaqI (rs731236). Наявність генотипу CC TaqI знижувала ризик прогресування ОП в 5,5 раз, а генотипу TT TaqI - підвищувала в 5,4 раза. Наявність мінорної алелі Т було асоційовано з більш високим вмістом інтерлейкіну $1 \beta$, МЩК і нижчим - тестостерону в крові. Мажорна гомозигота AA Cdx2 була виявлена у жінок без OП в 2,9 раза частіше, тоді як мінорний генотип GG - в 5,4 раза частіше за наявності ОП. Мажорної гомозигота знижувала ризик прогресії ОП більш ніж в 5,3 раза, тоді як мінорна підвищувала його в 8 разів. Наявність мінор- ної алелі $\mathrm{G}$ в генотипі було асоційовано з підвищенням у крові вмісту паратиреоїдного гормону, фосфору, магнію, активності лужної фосфатази, МЩК та зі зниженням вмісту прогестерону, тестостерону і кальцію.

Ключові слова: постменопаузний остеопороз; гормони; VDR; поліморфізм Cdx2 (rs11568820); поліморфізм TaqI (rs731236)

\section{Д. С. Зяблицев, А. С. Ларин \\ ВЛИЯНИЕ ОДНОНУКЛЕОТИДНЫХ ПОЛИМОРФИЗМОВ ГЕНА VDR НА УРОВЕНЬ ОСТЕОАССОЦИИРОВАННЫХ ГОРМОНОВ ПРИ ПОСТМЕНОПАУЗНОМ ОСТЕОПОРОЗЕ}

В плазме крови 74 женщин в постменопаузном периоде с и без остеопороза (ОП) определяли содержание остеоассоциированных гормонов, макроэлементов, интерлейкинов, циклических нуклеотидов и активность щелочной фосфатазы. Минеральную плотность кости (МПК) и метакарпальный индекс оценивали по результатам денситометрии. С помощью полимеразной цепной реакции определяли аллельные полиморфизмы 
гена рецептора витамина D (VDR) Cdx2 (rs11568820) и TaqI (rs731236). Присутствие генотипа CC TaqI снижала риск развития ОП в 5,5 раза, а генотипа TT TaqI повышала в 5,4 раза. Присутствие минорной алели Т было ассоциировано с более высокими уровнями интерлейкина $1 \beta$, МПК и низким уровнем тестостерона в крови. Мажорная гомозигота AA Cdx2 была выявлена у женщин без ОП в 2,9 раза чаще, тогда как минорный генотип GG - в 5,4 раза чаще при наличии ОП. Мажорной гомозигота снижала риск развития ОП более чем в 5,3 раза, тогда как минорная повышала его в 8 раз. Присутствие минорной аллели $\mathrm{G}$ в генотипе было ассоциировано с повышением содержания паратиреоидного гормона, фосфора, магния, активности щелочной фосфатазы в крови, МПК и со снижением уровней в крови прогестерона, тестостерона и кальция.

Ключевые слова: постменопаузальный остеопороз; гормоны; VDR; полиморфизм Cdx2 (rs11568820); полиморфизм TaqI (rs731236)

\section{REFERENCES}

1. Kulakov VI, Manukhin IB, Soloveva Gynecology: National Guidness. 2011: 848. [Russian].

2. Yakushevskaya OV, Yureneva SV. Pathogenetic bases of the sharp phase development of the response to intravenous administration of nitrogen-containing bisfosfonat. Obstetrics and Gynecol. 2013;5: 19-23. [Russian].

3. Mishchenko EB. Importance assessment of the external and internal risk factors of osteoporosis development. Intern Endocrinol J. 2011. 1 (33): 15-21. [Russian].

4. Bischoff L., Derk CT. Premenopausal osteoporosis. Minerva Medica J. 2008: 99 (1): 55-63.
5. Povoroznyuk VV, Masik NP, Pirogova NI, 2015. Bone tissue markers and their clinical value at a chronic obstructive pulmonary disease. Health of Kazakhstan 202/33:50-8. [Russian].

6. Haussler MR, Whitfield GK, Kaneko I. Molecular mechanisms of vitamin D action. Calcified Tissue Internat. 2013. 92 (2): 77-98.

7. Schunack W. Vitamin D3 a prodrug of different D3hormones. 101 Suppl 1: Medizinische Klinik (Munich, Germani). 2006 Jun 20-24: 20-4.

8. Li WF, Hou SX, Yu B, Li MM. Genetics of osteoporosis: accelerating pace in gene identification and validation. Human Genetics. 2010. 127 (3): 249-285.

9. Casado-Díaz A, Cuenca-Acevedo R, Navarro-Valverde C. Vitamin D status and the Cdx-2 polymorphism of the vitamin D receptor gene are determining factors of bone mineral density in young healthy postmenopausal women. Molecul Biol. 2012: 0960 (12): 192-6.

10. Baig L, Mansuri FA, Karim SA. Association of menopause with osteopenia and osteoporosis: results from population based study done in Karachi. J Coll Physic and Surg Pakistan. 2009; 19 (4): 240-4.

11. Jia F, Sun RF, Li QH, Wang DX, Zhao F, Li JM, Pu Q, Zhang ZZ, Jin Y, Liu BL, Xiong Y. Genetical Testing of Molecular Biomarkers. 2015; 30-34. PubMed doi:10.1089/ gtmb.2012.0267.

12. Xu H, Li S, Qiu JQ, Gao XL, Zhang P, Yang YX. The VDR gene Fok I polymorphism and ovarian cancer risk. Tumour Biol: 2013 Dec; 3309-16.

13. Ziablitsev DS, Pishchulina SV, Kishenya MS, Chernobrivtsev AP. Value of vitamin D receptor gene polymorphisms in the pathogenesis of osteodeficiency of postmenopausal period women. Morph Bull. 2014; 2 (20): 432-5. [Russian]. 